\title{
Inter-islands Dynamic Economy: Colonial Policy on the Indonesian Ports Development for International and Domestic Shipping during Colonial Times
}

\author{
Haryono Rinardi, ${ }^{1 *}$ Yety Rochwulaningsih ${ }^{2}$ \\ ${ }^{1}$ Department of History, Faculty of Humanities, Universitas Diponegoro, Indonesia \\ ${ }^{2}$ Doctoral Program of History, Faculty of Humanities, Universitas Diponegoro, Indonesia
}

DOI: https://doi.org/10.14710/jmsni.v4i1.7899

\begin{abstract}
As a capital-intensive transport technology linked to Received: industrialized economies, ports become more essential economic infrastructure for developing periphery. Using the historical method, this article examines the relations between ports construction and the development of the voyages of the Indonesian archipelago, which was before called the Dutch East Indies. Based on the results, the port's construction caused by several factors. First, the colonial government wanted to reduce Singapore's role as an entre-port for the Dutch East Indies shipping activities, so that several ports been developed in the

May 26, 2020

Revised:

June 13, 2020

Accepted:

June 13, 2020

*Corresponding Author:

haryonorinardi@lecturer.undip.ac.id outer islands of Java. Second, ports development in outer islands became one of the Dutch economic expansions. Third, to relinquish reliance on foreign shipping companies, the colonial government then developed KPM and gave a monopoly right of shipping across the islands. Fourth, the utilization of modern ship engines in shipping led the growing up international voyages and had prompted the government to develop ports. Another interesting finding from this article is the relation between shipping and trade, the port constructions in various parts of the Dutch East Indies has encouraged trading networks developed in the area.
\end{abstract}

Keywords: Outer Islands; Disparity; Port Infrastructure; Regional Economy.

\section{Introduction}

Economic relation between areas or islands already exists in the Archipelago since the premodern era, which later politically becomes Indonesian since the fifth century. In this case, there is a symbiotic relationship between Java and outer islands. Ecologically, Java is a rice field area. The areas outer islands of Java are the shifting cultivation area. Java is a food crop producing area, rice, that is exported to the shifting cultivation area (Van Leur, 1983). ${ }^{1}$ On the other hand, shifting cultivation area produces crops that are saleable well in international markets such as; nutmeg, clove, pepper, forest product and mine. However, the areas outer Java do not produce food crops. They need food supplies from other areas. With this condition, there is a symbiotic relationship through mutually beneficial trade between the two areas, with Java as a center, while the areas outer Java act as a kind of periphery.

Trade dealers along the north coast of Java played an important role in shipping and trading activities in those days. Therefore, Java acted as an axis of trading and shipping activities during precolonial times (Dick, 1975). Therefore, it is natural for Pasuruan to be a trading center in Java. The construction was then followed by the expansion of the rail network throughout Java (Dick, 1993). Initially, the construction was handed over to private parties, but since the 1880 s the government

${ }^{1}$ In 1615 , it was estimated that there were 50 rice junks shipping from Jepara to Malacca each year. In addition, there was still a lot of junks sailed carrying rice to Banten, Johor, Patani, Jambi, and Palembang. It was estimated that there were about two hundred junks carrying rice for export to the outer island of Java. Each junk carried a hundred tons of rice. 
began to play a more constructive role. The construction of the rail network was expanded, so that it was able to cover all important areas in Java. At the end of Dutch colonial, Java had an integrated rail transport network, ranging from the eastern to the western end. In overall by the twentieth century, Java has had a large modern manufacturing sector to process primary commodities, both agricultural crops (especially sugar) and raw materials (especially petroleum), which are related to machinery and metal. Java has also developed the manufacturing sector for general needs and a few types of consumer goods and as well as buildings (Dick 1990).

A study by Airries (1955) proves that in the colonial period, port development in Sumatra underwent structural changes and oriented towards the transport of plantation products to meet global needs. The change includes maximizing the hinterland and foreland areas for the benefit of sea transportation. In addition, improvements to the port infrastructure in the North Sumatra region were carried out in order to combine two important elements, namely the space in the port and the waters that are connected to the transportation route. Airries also stated that there were morphological changes in the port transportation system in Sumatra. Externally, the development of the port area is caused by regional economic developments that shape transportation patterns (C. Airriess 1995). Airries in another study (1991) also took the case of the Port of Belawan as a representation of the development of the port area by the colonial government of several ports in Sumatra. The Port of Belawan functioned as one of the most productive primary outer island ports and even became a link with the international world (C. A. Airriess 1991). That was caused by the development of the plantation industry in the East Sumatra region. In addition, a study from Lindblad (1989) proves that there is an economic disparity that influence the infrastructure in the port slower in the outer islands because a lack of population. The outer island of Java exports the most plantation products through Java. As a result, port infrastructure was built only centralized in Java and a small portion of outer islands. Only a few regions, such as East Sumatra, North Sumatra, and South Kalimantan, have port infrastructure which connected to the international links. The rest, the port is built based on inter-island connectivity (Lindblad 1993). The purpose of the outer island ports development also discussed by Ota (2013) which states that the purpose of developing outer island ports infrastructure Java is used to meet the market share of China and Southeast Asia in general with commodities, pepper, typical plantation products, and coffee (Ota 2013). Therefore, this study takes part in the discussion of the colonial expansion efforts in outer islands by developing its port infrastructure. It analyzes based on the Wallerstein theory of a world system with an emphasis on economics (Guarini 1995) and the division of two major things that led interdependent center-periphery relations.

\section{New Development and Challenges of Colonial Shipping and Trading Sector}

New development in colonized land occurred when Suez Canal was opened in 1869. It made the distance between Europe and Asia shorter. The change caused the smooth flow of people, goods, and services from Europe to Asia and vice versa. On the other hand, it has caused the Dutch position in Indonesia that was only based on its nominal sovereignty outer islands to be threatened with the presence of other nations (Hall 1985). At the same time, the discovery of various minerals from outer islands had prompted the Colonial Government to pay more attention to the outer islands. The discovery of tin in Bangka, Belitung \& Singkep, then coal in Ombilin West Sumatra \& South East Kalimantan, gold in West Kalimantan, and petroleum in Sumatera and Samarinda became the impetus for the Colonial Government to manage and pay attention to the outer islands.

The development of the outer islands faced a problem that needed to be solved by the Colonial Government. The areas had long been linked to the British-controlled area. The areas of East Sumatra, and even Aceh had established cooperation in trade with Penang. Some areas in Sumatra, even Java itself also had developed trade activities with Singapore (Koh 2015). One thing to note is that England still controlled several areas in the archipelago at the beginning of the Dutch colonial government period, such as Tapanuli, Bengkulu, Bangka, and North Kalimantan. Here, Dutch colonial domain in the Indonesian archipelago was surrounded by British colonial territories, but also the enclave of British at the heart of Dutch territory. Therefore, it is only natural that British shipping and trading networks were capable of mastering shipping and trading activities in Indonesian 
archipelago. England also had power centers on Dutch East Indies areas such as Penang, Singapore, Brunei, Sabah, Sarawak, Hong Kong, and so on (Lee, Song, and Ducruet 2008). These port cities were shipping and trading centers in Southeast Asia and East Asia that would draw the indigenous trade of Dutch East Indies population, especially Singapore and Penang. In this relationship, they acted as center, while the outer island ports of Java as periphery. This is possible because the Dutch only focused on developing ports in Java, particularly Batavia. Consequently, the outer island ports Java were under the shadows and became the orbit of the ports under the British colonial.

Based on the conditions above, the efforts of the Dutch Colonial Government to enforce its power in outer islands were hindered by economic sector. The outer islands had been economically bound to the British-controlled areas namely, Penang and Singapore. Therefore, the development of the outer islands should pay close attention to its links with Penang and Singapore. Consequently, two options must be taken by the Colonial Government. First, became the part of the UK-controlled trading and shipping networks in the Indonesian Archipelago, which was based on Singapore and Penang. Second, they tried to cut the links by trying to reduce the role of Penang and Singapore.

The Colonial Government presumably preferred the second option. They tried to reduce and cut Singapore role in shipping and trading activities in the archipelago. Overall, the shipping activities in the archipelago until the end of the nineteenth century were still controlled by British shipping companies with Penang and Singapore as the center. Until 1890, all shipping to East and North Sumatra as well as to Kalimantan and Sulawesi were still controlled by Penang and Singapore. Goods from these areas were brought by British ships and then transferred in Penang and Singapore by other ships to other places, such as Europe, India, China and Australia. The Dutch shipping company was unable to deal with competition against British shipping companies. As an illustration of the helplessness of Dutch shipping companies in the world of transport and shipping in the archipelago at that time, Dutch officials and pilgrims from the archipelago would change ship in Singapore and Penang before continuing their journey to the Netherland and Arabian Peninsula (Reid 2002b). On that basis, it can be seen that the shipping in the archipelago still used Singapore and Penang as a gateway to the world shipping. In terms of trade, the role of Singapore was even greater. Singapore had always been able to locate areas outer islands of Java as part of the economic sub-system. The outer islands were a producer of raw materials that were then exported or processed first in Singapore to the international (Reid 2002a; Sulistiyono 2006). ${ }^{2}$ Therefore, it can be concluded that the economy of the archipelago until the late nineteenth and early twentieth century was more connected to Singapore and Penang compared to Batavia as the administrative center of the Dutch East Indies government at that time. So, the development of some growth centers in outer islands had to do with the efforts of the Colonial Government to reduce and cut the linkage and dependence of these areas with a new economic center in Southeast Asia, Singapore.

The growth of Singapore as an entrepot in Southeast Asia became a problem for the Colonial Government. The existence of Singapore might cause economic integration for all areas difficult to run. Traditionally, the outer islands had already had close ties with Singapore. The condition encouraged the Colonial Government to establish and develop new economic knots in the outer islands. The development and improvement of ocean ports in outer island is one way to establish and develop the economic knot. The development of the economic knot will encourage the growth and economic development of the surrounding area. On the other hand, the development of economic knot aimed to reduce and cut Singapore's role as an entrepot for the outer islands, encourage the creation of economic balance in the archipelago, as well as realize integration in the archipelago.

\section{Construction of Port Infrastructure in the Dutch East Indies}

The policy of the Dutch East Indies Colonial Government to cut and reduce the role of Singapore as a center for various ports in the archipelago was performed in two ways. First, they set some outer island ports as free ports. Second, built and developed the infrastructure of existing ports. Through that policy, the port of Batavia, Surabaya, Semarang, and then Riau, Muntok, Palembang, Bengkulu,

${ }^{2}$ Crude rubber from Sumatera area was mostly bought by Singapore fish merchant (tanke) to be processed and then exported through Singapore to international market. 
Padang, Tapanuli, Banjarmasin, Pontianak, Sambas, Makassar and Kupang were opened to serve the shipping of foreign ships for import in 1825 (Kok 1931). In 1839, Air Bangis, Singkel and Barus were declared as an international port (Indisch Staatsblad, No. 401841) followed by Muara Kumpeh in Jambi in 1847 (Indisch Staatsblad, No. 191847). Through these ports, various commodities from the Dutch East Indies were exported abroad. The Colonial Government, did the same for import procedures. Import commodities could only enter the ports mentioned above. Furthermore, imported goods will be distributed to smaller ports that were not used to serve international shipping and trading activities. Through the policy, the Colonial Government aimed to protect domestic shipping in Indonesian Archipelago, in particular from the expansion of Singaporean ships owned by British and Chinese companies (Kok 1931)

The next policy of colonial government was to develop transport infrastructure. In this regard, the opening of the Suez Canal had encouraged the Colonial Government to modernize its fleet where better facilities were required (Furnivall 1948; Rochwulaningsih et al. 2019). It was performed to transport export commodities to global markets. It was an integral part of the effort of improvement and development in Java. As a result, in Java, port and port accommodation, warehouse/storage goods, and other transportation facilities began to be developed The first modern ocean port built by the Colonial Government as part of the improvement and development plan was Batavia port in Tanjung Priok in 1877 (Gonggrijp 1928). The construction of Batavia port finished 1893 by spending 26.5 million (Furnivall 1939).

The policy was an attempt to divert some of Singapore's role as an enterport to Batavia. This was actually driven by an increase in export from the outer islands. Batavia Port, Tanjung Priok not only exported agricultural commodities from West Java, but also acted as a transit port for export of the commodities from outer islands such as tin from Bangka, coffee from Palembang, crude oil from Sumatra and Kalimantan (Clements 1922).

Port of Surabaya began to be developed in the late nineteenth century. The Port of Surabaya, Tanjung Perak is a natural harbor so it needs less complete construction like Tanjung Priok. Surabaya serves as a shipping and trading center for the eastern part of the Indonesian archipelago. Surabaya made some parts of the eastern islands of Indonesia as its hinterland, such as Bali, Lombok, Nusa Tenggara archipelago and southeastern of Kalimantan (Sulistiyono and Rochwulaningsih 2013). Surabaya was the biggest export gateway for sugar commodities. Rubber export from Java was mostly also shipped from Surabaya, but the number was relatively smaller compared to the exports from outer islands of Java. Surabaya imported more textiles, rice and machinery than Batavia.

Semarang was another important city in the Java Sea area. In international shipping, Semarang Port occupied the third place after Batavia and Surabaya. The construction of Semarang Port was relatively late compared to Batavia and Surabaya. In this case, initially there was no advantage from the large-scale government efforts to build new harbor or large port work. This comparative loss made it difficult for Semarang to participate fully in competitive shipping activities, even though the port has considerable regional interest. Therefore, Semarang had been left behind in the expansion of international shipping. The Port of Semarang was originally planned to be built in 1904 . The new harbor began to build in 1910, by extending the old port, especially in the east (Touwen 2001)

In the areas outer islands of Java, the Colonial Government also attempted to build port infrastructure and facilities. The Port of Makassar was built by the Colonial Government in 1900 as an attempt to cut Singapore's role in trading activities in Eastern Indonesia. The development of port facilities in the western part of Indonesia began with the development of Teluk Bayur port in Padang at the end of the nineteenth century. The port was originally used for the benefit of coal distribution from Ombillin via the Sea (Gonggrijp 1928). Belawan port was also developed by the Colonial Government in the early twentieth century. The port was intended to serve the area of North Sumatra.

Another important port outer island was Palembang. The city had been a center of commerce for centuries. Therefore, Palembang was visited more by many ships than other ports in southern Sumatra, such as Bentung Bay in Lampung, Bengkulu and Jambi (Wellan 1932). Port of Palembang is located on the Musi River and has a deep enough cruise line, so it can be used to sail up to the inland areas. However, due to the sandbar, access to the Palembang dock is hampered especially for 
ships with weight exceeds $2000 \mathrm{~m} 3$. In its development, there were three ports in Palembang in the 1930s. First, BPM on the south side of Musi River near Plaju refinery complex. Second, a public or a state-owned port that had a length of 250 meters. The port was located on the southern side of Musi river, it was also called a new boom. Third, the $250 \mathrm{~m}$ port in Kertapati that was about $5 \mathrm{~km}$ to the upstream.

Another important port developed outer island was Banjarmasin Port. The port is located on the Martapura River, not on the longer Barito River and becomes the estuary of Martapura River. Therefore, at the estuary of Barito River was always treated by dredging its silt. This was performed so that ships could sail into the Martapura river. The act of dredging the silt became the responsibility of the local government in South Kalimantan. In the first decade of twentieth century, Banjarmasin port could not be transited by large ships. The condition was different from Balikpapan port that was actually a nature. Port of Balikpapan is a port for the petroleum export in the east coast of Kalimantan. Another important port developed by the Dutch Colonial Government was Makassar. Makassar became a trading center in the eastern archipelago. Port of Makassar becomes the gateway for goods to be sent to the inland areas of Sulawesi or forwarded to Maluku or Papua. Instead, the land products from the eastern part of the archipelago was first sent to Makassar before being transported by ship to Java or even to the world. Interestingly, the average ship that transited at the Port of Makassar was larger than Pontianak. Shipping on the coast of Makassar was also more valuable than Pontianak or even Palembang (Touwen, 2001). They are all part of the Colonial Government's efforts to develop areas that were previously considered underdeveloped. Although in this case it is undeniable that there are other motives.

\section{Domestic Shipping and Trading}

One of the components involved in domestic shipping and trading activities in the archipelago until the early twentieth century was traditional sailboats. By the end of the nineteenth century the indigenous sailor involved in traditional ship shipping were Buginese, Makassarese, Madurese, Mandar, and Butonese. They operated in many areas or ports in the Indonesian Archipelago. In this case, the ports of Java Sea were the backbone of their activities. Mandar sailors were in Mandar Bay, the western coast of Sulawesi, located between Polewali and Mamuju. In that area there were several small ports, such as Binuang, Balangnipa, Majene, Pambauang, Tapapalang, and Mamuju. During the end of east wind season in October, Mandar ships sailed to Singapore, by visiting Ani Ani Island in Riau Islands first to get clean water. In Singapura, they sold kapok and rattan. Then, they bought items such as pottery, cotton, knives, household utensils, matches and so on. Many Mandar sailors also sailed to Penang Island. During the first half of December they began shipping back to Majene by using west monsoon. Other routes used by Mandar sailors were through Kalimantan and the northern coast of Java. In mid-east wind season (around July) many Mandar ships left for Kalimantan from Majene via Masalimo, southeastern Kalimantan, then head for Laut Island. From Laut Island, they sailed to Masalembo Islands. Then they could reach Bawean Island in Java Sea in 24 hours. Furthermore, they sailed to Karimunjava Islands and then to Semarang. Mandar ships from Semarang would probably continue the voyage to Batavia via Pekalongan, Tegal, Cirebon and Karawang (Sulistiyono 2006).

Mandar Coast is not only the only traditional Sulawesi sailboat. Bira, located at the southern tip of Sulawesi also became the center of Makassar's sailing ships. They sailed to the east until they reached the northwest coast of Papua in April and May (Macknight 1983). Furthermore, they continued their voyage to the west until Batavia, even many of them sailed to Singapore. The total distance traveled in each voyage could reach about seven thousand miles. In the east wind season, Makassar ships sailed to Banjarmasin, Gresik, Surabaya, Semarang, Batavia, Belitung, and Pontianak to trade various agricultural products. In the west wind season, they returned to Makassar via Belitung, Batavia, and other ports along the northern coast of Java, Sumbawa, western Flores, and Sumba. On the voyage, they brought forest and marine products to trade.

Madurese sailors were also involved in many shipping activities in the archipelago. They departed from Madura and the small islands located in east of Madura at the beginning of the year. They usually carried salt obtained from Surabaya for sale in Lombok. Then, they sailed to Sawu to buy palm sugar before shipping to the south where corals cluster in between Timor and the Kimberley 
Coast in Australia were located. They were looking for seafood ranging from sea cucumber, turban shell, clam meat, and so on. They continued to sail northward, in the coastal area of Makassar to sell marine products and bought coconut and copra which later would be sold to Surabaya.

Based on the above note it can be seen that the role of traditional sailboat is still important during the early twentieth century. Shipping using traditional ship by sailors and people from Eastern Indonesia plays an important role in inter island trade in the early twentieth century. About the number and volume of traditional ships in the Port of Surabaya, Banjarmasin and Makassar can be shown in the Table 1.

Table 1 Number and volume of Coastal Shipping using ship anchored in Surabaya, Makassar, and Banjarmasin in $1898-1910$ (volume in $\mathrm{m}^{3}$ )

\begin{tabular}{lllllllllllll}
\hline Year & \multicolumn{1}{c}{ Surabaya } & \multicolumn{3}{c}{ Makassar } \\
\cline { 2 - 5 } & \multicolumn{3}{c}{ Indigenous } & Europe & \multicolumn{3}{c}{ Indigenous } & \multicolumn{3}{c}{ Europe } & \multicolumn{3}{c}{ Indigenous } \\
& Number & Vol. & Number & Vol. & Number & Vol. & Number & Vol. & Number & Vol. & Number & Vol. \\
1898 & 49 & 23 & 79 & 6 & 10 & 8 & 101 & 3 & 115 & 31 & 0 & 0 \\
1899 & 36 & 18 & 74 & 8 & 2 & 0 & 137 & 3 & 110 & 28 & 0 & 0 \\
1900 & 47 & 25 & 85 & 8 & 2 & 0 & 494 & 10 & 117 & 41 & 990 & 15 \\
1901 & 48 & 31 & 97 & 7 & 1 & 0 & 227 & 5 & 106 & 30 & 211 & 3 \\
1902 & 27 & 15 & 129 & 10 & 1 & 1 & 169 & 4 & 79 & 22 & 900 & 14 \\
1903 & 15 & 10 & 130 & 9 & 0 & 0 & 124 & 3 & 60 & 17 & 732 & 13 \\
1904 & 10 & 5 & 98 & 6 & 0 & 0 & 123 & 2 & 56 & 11 & 572 & 11 \\
1905 & 6 & 4 & 90 & 5 & 0 & 0 & 142 & 2 & 73 & 19 & 210 & 5 \\
1906 & 7 & 3 & 89 & 5 & 0 & 0 & 180 & 3 & 50 & 12 & 207 & 5 \\
1907 & 10 & 5 & 81 & 5 & 1 & 2 & 364 & 8 & 51 & 17 & 219 & 5 \\
1908 & 5 & 2 & 104 & 5 & 0 & 0 & 328 & 8 & 92 & 23 & 260 & 6 \\
1909 & 6 & 1 & 76 & 5 & 1 & 1 & 285 & 6 & 51 & 10 & 208 & 5 \\
1910 & 14 & 10 & 41 & 2 & 1 & 1 & 244 & 6 & 55 & 10 & 218 & 5 \\
\hline
\end{tabular}

Based on Table 1, it can be seen that until the turn of the twentieth century ship shipping still played a small role in shipping and trading activities in the archipelago. Surabaya is the most important port in coastal shipping for the eastern archipelago. Overall, Surabaya even had equal position with Batavia Port in coastal or domestic shipping since 1880 (Touwen 2000). The table above also shows that both in Makassar and Banjarmasin coastal shipping by sailboat still plays a role that could not be underestimated, if not considered important. Many indigenous traditional ships were involved in coastal shipping activities. Interestingly, many European shipping companies were also involved in shipping. In the case of the Port of Makassar, the number of ship arrivals owned by European companies in Surabaya was quite large. It might be related to several things. First, the involvement of foreign shipping companies in shipping activities in the archipelago were restricted by the government. Second, it was related to the natural conditions in the archipelago that enabled the development of traditional shipping using sailboats (Reid 1983). ${ }^{3}$ Third, traditional shipping and trading activities still existed and developed in Indonesian Archipelago. This was because in the interisland, the volume of goods traded in trading activities was not much so it was more profitable by using a traditional boat. Another factor was, although the Colonial Government had tried to develop some ports, its supporting infrastructure was still inadequate. Therefore, the use of traditional ships as a means of sea transportation was considered more profitable. The interesting thing was the average cargo capacity of shipping ship in the archipelago increased during the 1875-1910. In 1875, the average cargo capacity of sailboats reached $25 \mathrm{M} 3$. That number increased to $28 \mathrm{~m}^{3}$ in 1910 (J. N. F. M. à Campo 2007). On that basis, it makes sense that sailboats were still actively involved in shipping and trading activities even for the largest ports of the Dutch East Indies, Batavia and/or other western ports, such as Palembang and Pontianak. It can be seen in the Table 2.

${ }^{3}$ The existence of predictable monsoon wind is very helpful for traditional shipping activities. At the same time, the water in the archipelago does not contain much salt, making wooden ships more durable. In this water, storm only blows in the suburbs so as not to harm the voyage. 
Table 2. Number and Volume of Coastal Shipping using Sailboat in Batavia, Palembang, and Potianak in 1898-1910

\begin{tabular}{|c|c|c|c|c|c|c|c|c|c|c|c|c|}
\hline \multirow{3}{*}{ Year } & \multicolumn{4}{|c|}{ Batavia } & \multicolumn{4}{|c|}{ Palembang } & \multicolumn{4}{|c|}{ Pontianak } \\
\hline & \multicolumn{2}{|l|}{ Europe } & \multicolumn{2}{|c|}{ Indigenous } & \multicolumn{2}{|c|}{ Europe } & \multicolumn{2}{|c|}{ Indigenous } & \multicolumn{2}{|l|}{ Europe } & \multicolumn{2}{|c|}{ Indigenous } \\
\hline & Number & Vol. & Number & Vol. & Number & Vol. & Number & Vol. & $\begin{array}{l}\text { Numbe } \\
\mathrm{r}\end{array}$ & Vol. & $\begin{array}{l}\text { Numbe } \\
\mathrm{r}\end{array}$ & Vol. \\
\hline 1898 & 79 & 37 & 187 & 6 & 39 & 17 & 154 & 9 & 3 & 2 & 56 & 1 \\
\hline 1899 & 76 & 40 & 234 & 7 & 33 & 19 & 375 & 11 & 5 & 3 & 33 & 1 \\
\hline 1900 & 86 & 49 & 229 & 8 & 15 & 10 & 358 & 10 & 4 & 2 & 11 & 0 \\
\hline 1901 & 68 & 26 & 237 & 9 & 21 & 11 & 377 & 12 & 8 & 4 & 12 & 1 \\
\hline 1902 & 73 & 24 & 241 & 8 & 24 & 10 & 338 & 12 & 5 & 2 & 17 & 1 \\
\hline 1903 & 70 & 36 & 197 & 7 & 20 & 10 & 346 & 12 & 4 & 2 & 24 & 1 \\
\hline 1904 & 51 & 33 & 253 & 9 & 44 & 14 & 353 & 12 & 9 & 5 & 54 & 1 \\
\hline 1905 & 103 & 17 & 211 & 8 & 25 & 13 & 369 & 12 & 5 & 3 & 78 & 1 \\
\hline 1906 & 113 & 29 & 218 & 8 & 35 & 14 & 331 & 12 & 0 & 0 & 109 & 1 \\
\hline 1907 & 77 & 33 & 282 & 11 & 30 & 13 & 353 & 12 & 1 & 2 & 136 & 2 \\
\hline 1908 & 94 & 39 & 102 & 5 & 42 & 10 & 329 & 12 & 2 & 2 & 107 & 2 \\
\hline 1909 & 112 & 52 & 204 & 5 & 62 & 17 & 317 & 10 & 0 & 0 & 134 & 5 \\
\hline 1910 & 59 & 32 & 238 & 12 & 87 & 30 & 251 & 8 & 2 & 3 & 104 & 1 \\
\hline
\end{tabular}

Source: L.J. Touwen, Shipping and Trade, p. 84-85, 93, 97.

Based on the above data it is known that shipping by sailboat was not only performed by Indigenous traditional sailors, but also by the European shipping company. The table above also shows that although Batavia Port had been built as a modern port, it did not eliminate traditional shipping roles and activities that use sailboats. The port of Batavia was still visited by a sailboat owned by both Europe and Indigenous companies. Compared to the other two ports, Palembang and Pontianak, Batavia was far superior in both the number of arrival and volume. At smaller ports that served the eastern part of the archipelago, sailboat shipping also played an important role.

Although inter-island shipping in the archipelago still widely used sail boat, using motorized ships began to develop since the mid-nineteenth century. Batavia became the most visited port by steamboats for domestic shipping. Table 3 can show the progress of the number and volume of ship traveling to the port of Batavia, Palembang, and Pontianak.

Table 3. Number and Volume of Coastal Shipping using Steamboat that transited in Batavia, Palembang and Potianak in 1898-1910

\begin{tabular}{lllllll}
\hline Year & \multicolumn{3}{c}{ Batavia } & \multicolumn{2}{c}{ Palembang } & \multicolumn{2}{c}{ Pontianak } \\
& Number & Volume & Number & Volume & Number & Volume \\
\hline 1898 & 339 & 587 & 51 & 72 & 16 & 17 \\
1899 & 214 & 357 & 74 & 104 & 22 & 24 \\
1900 & 261 & 404 & 54 & 62 & 22 & 26 \\
1901 & 232 & 382 & 136 & 205 & 49 & 40 \\
1902 & 331 & 1.019 & 91 & 155 & 69 & 52 \\
1903 & 370 & 1.088 & 147 & 184 & 68 & 47 \\
1904 & 411 & 1.035 & 188 & 223 & 6 & 6 \\
1905 & 330 & 1.066 & 130 & 199 & 32 & 48 \\
1906 & 358 & 1.272 & 174 & 229 & 24 & 34 \\
1907 & 376 & 1.356 & 204 & 241 & 17 & 34 \\
1908 & 421 & 1.440 & 200 & 228 & 26 & 50 \\
1909 & 486 & 1.778 & 226 & 322 & 15 & 27 \\
1910 & 577 & 2.256 & 227 & 322 & 28 & 52 \\
\hline \multicolumn{6}{c}{ Source: Touwen 2000, 84-85, 93, 97. }
\end{tabular}

Based on the data in the above table, it can be seen that there is an interesting development in coastal or domestic shipping by using steamboat during the early twentieth century. There was an 
increase in the use of steamboat for coastal shipping at the three ports in the western archipelago, with a few exceptions in Pontianak. This harbor was visited by 69 ships until 1902, the highest during 1898-1910. However, after that decline, there were fluctuations in the arrival of ship for domestic shipping in 1908-1910 period. The constant increase in the number of ships in the three ports indicates the improvement of port infrastructure and the increasing use of motorized ship that began to shift shipping boat. On the other hand, it can also indicate the increasing volume of trade in various areas of archipelago as Table 4 stated.

Table 4. Number and Volume of Coastal Shipping using Steamboat that transited in Batavia, Palembang and Potianak in 1898-1910 (volume in $1000 \mathrm{~m}^{3}$ )

\begin{tabular}{|c|c|c|c|c|c|c|}
\hline \multirow[t]{2}{*}{ Year } & \multicolumn{2}{|c|}{ Batavia } & \multicolumn{2}{|c|}{ Palembang } & \multicolumn{2}{|c|}{ Pontianak } \\
\hline & Number & Volume & Number & Volume & Number & Volume \\
\hline 1898 & 339 & 587 & 51 & 72 & 16 & 17 \\
\hline 1899 & 214 & 357 & 74 & 104 & 22 & 24 \\
\hline 1900 & 261 & 404 & 54 & 62 & 22 & 26 \\
\hline 1901 & 232 & 382 & 136 & 205 & 49 & 40 \\
\hline 1902 & 331 & 1.019 & 91 & 155 & 69 & 52 \\
\hline 1903 & 370 & 1.088 & 147 & 184 & 68 & 47 \\
\hline 1904 & 411 & 1.035 & 188 & 223 & 6 & 6 \\
\hline 1905 & 330 & 1.066 & 130 & 199 & 32 & 48 \\
\hline 1906 & 358 & 1.272 & 174 & 229 & 24 & 34 \\
\hline 1907 & 376 & 1.356 & 204 & 241 & 17 & 34 \\
\hline 1908 & 421 & 1.440 & 200 & 228 & 26 & 50 \\
\hline 1909 & 486 & 1.778 & 226 & 322 & 15 & 27 \\
\hline 1910 & 577 & 2.256 & 227 & 322 & 28 & 52 \\
\hline
\end{tabular}

Source: Touwen, 2000.

Table 5. Number and Volumes of Coastal Shipping using Steamboat that transited in Surabaya, Makassar and Banjarmasin in 1898-1910 (volume in $1000 \mathrm{~m}^{3}$ )

\begin{tabular}{|c|c|c|c|c|c|c|}
\hline \multirow[t]{2}{*}{ Year } & \multicolumn{2}{|c|}{ Surabaya } & \multicolumn{2}{|c|}{ Makassar } & \multicolumn{2}{|c|}{ Banjarmasin } \\
\hline & Number & Volume & Number & Volume & Number & Volume \\
\hline 1898 & 228 & 442 & 211 & 525 & 71 & 93 \\
\hline 1899 & 254 & 518 & 208 & 536 & 68 & 82 \\
\hline 1900 & 221 & 488 & 185 & 536 & 73 & 91 \\
\hline 1901 & 207 & 464 & 182 & 556 & 60 & 89 \\
\hline 1902 & 196 & 425 & 198 & 613 & 66 & 85 \\
\hline 1903 & 244 & 557 & 251 & 872 & 88 & 160 \\
\hline 1904 & 233 & 554 & 258 & 982 & 52 & 114 \\
\hline 1905 & 244 & 589 & 281 & 979 & 49 & 97 \\
\hline 1906 & 245 & 617 & 292 & 1.076 & 52 & 112 \\
\hline 1907 & 257 & 682 & 285 & 1.069 & 54 & 116 \\
\hline 1908 & 265 & 660 & 183 & 590 & 48 & 121 \\
\hline 1909 & 281 & 671 & 192 & 599 & 51 & 114 \\
\hline 1910 & 249 & 719 & 204 & 599 & 1 & 0 \\
\hline
\end{tabular}

There are two interesting phenomena that can be seen from the table above. First, Palembang was a fairly busy port in the western Indonesian Archipelago. Based on the data on the table above, it is known that the number and volume of steamboat that transited in Palembang far surpassed Pontianak. However, when compared to Batavia, Palembang is still far behind especially in terms of ship tonnage that stopped. This is probably because the Port of Palembang has sandbar near the port, making it difficult for ships weighing over 2000 tons that wanted to anchor. Second, Batavia was the busiest port used as a stopover for steamboat with the development of infrastructure that had been done by the Colonial Government since 1877. Batavia became an entrepot for various outer islands. 
Before the various commodities were exported abroad, they were shipped first to Batavia. Therefore, the port of Tanjung Priok was visited by many ships carrying export commodities, to be sent abroad via Tanjung Priok Port in Batavia (Clements 1922). With such a background, Batavia surpassed Surabaya as the port transited by most ships. Table 5 shows the volume and number of ships that transited in Surabaya, Banjarmasin and Makassar.

The data in the Table 5 shows that the number and volume of ships that transited at the Port of Surabaya and Makassar are almost balanced. This is not surprising because Surabaya was Makassar partner in shipping and trading in the eastern archipelago. Although the number of ships visiting Surabaya area was greater, Makassar recorded greater volume than Surabaya until 1908. After that, Surabaya surpassed both Makassar both on the number and volume of ships that transited at the port.

\section{International Shipping}

International shipping has been performed for centuries before the arrival of the West Nation. Although it still referred to as a coastal shipping that travels through one port to the next port located along the Asian shipping and trade route. The route stretched from East Asia to the Mediterranean coast of Europe. These activities continued to grow and survive until the emergence of power of the Dutch East Indies Colonial Government in the Indonesian Archipelago, although the subject and route were different.

International shipping in the Dutch East Indies relates to the development of the Dutch fleet driven by Henry with the effort to rebuild the Dutch fleet of ship. As a result, in the 1875-1911 international shipping in Dutch East Indies increased by $7.1 \%$. This is probably related to the implementation of liberal policy in the Dutch East Indies since 1870. Another factor was the creation of two Dutch international shipping companies Stoomvaart-Maatschappij Nederland (SMN) and Rotterdamsche Lloyd (RL) in 1870 and 1873. One important factor was the establishment of a shipping company of Koninklijk Paketvaart Maatschappij (KPM) 1888 that got the monopoly right of sending letters to the colonial government replacing the Nederlandsch Indische Stoomboot Maatschappij (NISM) (Furnivall 1939). It opened of the shipping route from the Dutch East Indies to Europe (Campo 2003) In addition, it also made the development of economic expansion to the outer islands. The increase in international shipping in the Dutch East Indies was also due to the use of steamboat that had begun to dominate the world shipping since the third quarter of the nineteenth century (Sulistiyono \& Rochwulaningsih, 2013).

International shipping in Dutch East Indies during the early twentieth century was still dominated by Java ports. There were three main ports in Java visited by many ships that had international shipping routes. The ports were Batavia, Surabaya, and Semarang. Table 6 illustrates the great role of Java ports in international shipping in Dutch East Indies during the early twentieth century.

Based on Table 6, it can be concluded that Batavia was the main port for international shipping. Batavia far surpassed Surabaya in international shipping activities, including in the volume of its ships (Touwen, 2000). This situation is related to the policies that promote Batavia as a center of trade, as well as efforts to develop new industrial areas in Tanjung Priok (Clements, 1922). One interesting phenomenon appears in Table 7 data above, i.e the number of international ships visiting Palembang. In certain period the number even surpassed Surabaya. This is because Palembang was a producer of various export commodities, both agricultural products and mining materials, such as oil and coal Compared to the other outer islands, Palembang's export volume was the largest during the early period of the twentieth century (Touwen, 2001). Palembang was a producer of rubber and coffee that is not only cultivated by Indigenous people but also Western people. Other commodities exported from by Palembang was gutta-percha. Compared to other places, Palembang even occupied the first position as exporter of Gutta-percha for the Dutch East Indies. Therefore, the purpose of the ships that stop Palembang was to export the commodities produced from the southern part of Sumatra.

Another interesting phenomenon of the data in table 5 is the existence of Muntok as one of the ports that transited by many international ships. Based on the data in table 7 above, it can be seen that Muntok busyness as a port for international ships exceeded Pontianak. It became interesting, because Muntok is just a city in Bangka, compared with Banjarmasin that is one of the big cities in Kalimantan area. This is because Muntok is an export port for tin produced by Bangka, Belitung and 
other small islands in Riau Archipelago. For the record, in the period 1907-1908 the number of Bangka tin production was 11.515 tons, Belitung 4000 tons, and Singkep 40 tons (Cabaton, 2015).

The data in Table 6 shows that Pontianak is an important port for international shipping. Except with Palembang, Pontianak surpassed other outer island ports as a place for ship international transit. This is because port of Pontianak exported almost all commodities export of Dutch East Indies agricultural products, ranging from Gutta-percha, rubber, to copra (Touwen, 2000). On the other hand, Pontianak also imported many commodities, such as; textiles, machines, and rice. In the period 1908-1917, the rice import of Pontianak even outperformed all other important outer island (Touwen, 2000). That is why, Pontianak became one of the important transit places for international ships in the Dutch East Indies.

Table 6. Number of International Shipping Ship at Several Ports in Java and Outer Island Ports (Average for Ten Years)

\begin{tabular}{lllllll}
\hline Period & \multicolumn{7}{c}{ Javanese Ports } \\
\cline { 2 - 7 } & Batavia & Cirebon & Semarang & Surabaya & Panarukan & Banyuwangi \\
\hline $1880 / 90$ & 196 & 43 & 141 & 170 & 18 & 1 \\
$1890 / 99$ & 177 & 21 & 148 & 157 & 14 & 3 \\
$1900 / 09$ & 194 & 30 & 169 & 133 & 11 & 6 \\
$1910 / 19$ & 252 & 25 & 165 & 138 & 10 & 19 \\
\cline { 2 - 7 } & \multicolumn{7}{c}{ Outer Island Ports } \\
\cline { 2 - 7 } $1880 / 90$ & 88 & 29 & 118 & 16 & 61 & 0 \\
$1890 / 99$ & 128 & 33 & 145 & 11 & 32 & 3 \\
$1900 / 09$ & 202 & 21 & 154 & 52 & 32 & 26 \\
$1910 / 19$ & 157 & 38 & 134 & 29 & 28 & 16 \\
\hline
\end{tabular}

Source: Touwen 2000, 10.

International shipping in Dutch East Indies is likely to be related to trading activities, particularly export and import, not related to human traffic. On that basis, the reason why many ports are visited by ships with international shipping route is because those ports export or import commodities of various goods and other needs for the area.

\section{Conclusion}

The construction of port for shipping in Dutch East Indies is caused by several factors. First, it relates to the development of Singapore as an enterport. It causes the Colonial Government to open several ports in the Dutch East Indies into free ports. In that way, it is expected that the dependence of the Dutch East Indies on Singapore can be reduced. Second, Colonial Government intends to develop several ports in the Dutch East Indies as a way to expand the economy to the ouislands. Third, the colonial government intends to escape its dependence on foreign companies, the NISM that has previously dominated the shipping of Dutch East Indies with the establishment of KPM shipping to reduce the dependence. Fourth, the use of steamboat has led to the development of ocean ports in Dutch East Indies. At the same time, there are also international shipping activities in Dutch East Indies.

On the other hand, the development of port and shipping in the Dutch East Indies is intertwined with one another. The ports in the Dutch East Indies are built and developed to serve shipping activities, especially international shipping requiring better facilities. At the same time, there are also trading activities, especially import-export from the hinterland area of the port. The development of Muntok port is a real example of that case.

The last thing that can be drawn as a conclusion is that domestic shipping activities using shipping ship still exist and develop in the Dutch East Indies, even though steamboat has been used. This is because basically the people in the Dutch East Indies is a maritime community that mostly lives from traditional shipping and trading activities. Therefore, shipping and trading activities using traditional sailboats still survive despite the existence of steamboat. 


\section{Acknowledgement}

This article is part of research project funded by Institute for Research and Community Services [Lembaga Penelitian dan Pengabdian kepada Masyarakat] scheme Research Professorship Program, Diponegoro University, 2017.

\section{References}

Airriess, C. A. 1991. "Global Economy and Port Morphology in Belawan, Indonesia." Geographical Review 81 (2): 183-96.

Airriess, Christopher. 1995. "Port-Centered Transport Development in Colonial North Sumatra." Indonesia 59 (April): 65-91. https://doi.org/10.2307/3351128.

Campo, J. N F M. 2003. "Gauging the Historical Dimension of Globalization : The Case of Maritime Piracy in Insular Southeast Asia." International Journal of Maritime History 15 (1): 159-75.

Campo, J.N.F.M. à. 2007. "Asymmetry, Disparity and Cyclicity: Charting the Piracy Conflict in Colonial Indonesia." International Journal of Maritime History 19 (1): 35-62. https://doi.org/10.1177/084387140701900104.

Clements. 1922. Regional Patterns in Foreign Trade 1911-1940. Amsterdam: Royal Tropical Institute.

Dick, Howard. 1990. "Interisland Trade, Economic Integration, and the Emergence of the National Economy." In Indonesian Economic History in the Dutch Colonial Era, edited by Anne Booth, Malley W.J.O, and Anna Widemann, 312. New Haven: Yale University.

Furnivall, J.S. 1939. Netherlands India, A Study of Plural Economy. London: Cambridge University Press.

Furnivall, J.S. 1948. Netherlands Colonial Policy and Practice: A Comparative Study of Burma and Netherlands Indie. Cambridge: Cambridge University Press.

Gonggrijp, G. 1928. Schets Eener Ekonomische Geschiedenis van Nederlandsch-Indie. Haarlem: Derven F. Bohn.

Guarini, Elsa Fasano. 1995. "Center and Periphery." The Journal of Modern History 67 (December 1995): S74-96.

Hall, Kenneth R. 1985. Maritime Trade and State Development in Early Southeast Asia. Honolulu: University of Hawaii Press.

Indisch Staatsblad, No. 19. 1847.

Indisch Staatsblad, No. 40.1841.

Koh, Keng We. 2015. "Travel and Survival in the Colonial Malay World: Mobility, Region, and the World in Johor Elite Strategies, 1818-1914.” Journal of World History 25 (4): 559-82. https://doi.org/10.1353/jwh.2015.0001.

Kok, J.A. 1931. De Scheepvaartbescherming in Nederlandsch-Indië. Leiden: Leidsche UitgeversMaatschappij.

Lee, Sung Woo, Dong Wook Song, and César Ducruet. 2008. “A Tale of Asia’s World Ports: The Spatial Evolution in Global Hub Port Cities.” Geoforum 39 (1): 372-85. https://doi.org/10.1016/j.geoforum.2007.07.010.

Lindblad, J .Thomas. 1993. "Economic Growth in the Outer Islands 1910-1940." In New Challenges in the Modern Economic History of Indonesia, 233-63. Leiden: PRIS.M

Macknight, C.C. 1983. "The Nature of Early Maritime Trade: Some Points of Analogy From Eastern Part of The Indonesian Archipelago." In India and Maritime South East Asia: A Lasting Relationship, edited by J.G. De Casparis. Kuala Lumpur: University of Malaya.

Ota, Atsushi. 2013. "Tropical Products out, British Cotton in: Trade in the Dutch Outer Islands Ports, 1846-1869.” Southeast Asian Studies 2 (3): 499-526.

Reid, Anthony. 1983. Slavery, Bondage and Dependency in Southeast Asia. St. Lucia: University of Queensland Press. 
Reid, Anthony. 2002a. "Mata Rantai Perak, Mata Rantai Baja: Politik Pemaksaan Atas Geografi, 1865-1965." In Fondasi Historis Ekonomi Indonesia, edited by J .Thomas Lindblad, 342. Yogyakarta: Pusat Studi Sosial Asia Tenggara dan Pustaka Pelajar.

Reid, Anthony. 2002b. Sejarah Modern Awal Asia Tenggara. Jakarta: LP3ES.

Rochwulaningsih, Y., S.T. Sulistiyono, N.N. Masruroh, and N.N. Maulany. 2019. "Marine Policy Basis of Indonesia as a Maritime State: The Importance of Integrated Economy." Marine Policy 108. https://doi.org/10.1016/j.marpol.2019.103602.

Sulistiyono, Singgih Tri, and Yety Rochwulaningsih. 2013. "Contest for Hegemony: The Dynamics of Inland and Maritime Cultures Relations in the History of Java Island, Indonesia." Journal of Marine and Island Cultures 2 (2): 115-27. https://doi.org/10.1016/j.imic.2013.10.002.

Sulistiyono, Singgih Tri. 2006. "The Expulsion of KPM and Its Impact on the Inter-Island Shipping and Trade in Indonesia, 1957-1964.” Itinerario 30 (02): 104. https://doi.org/10.1017/S016511530001398X.

Touwen, L.J. 2000. Shipping And Trade In The Java Sea Region. Semarang: UNDIP Press.

Touwen, L.J. 2001. Extremes in the Archipelago: Trade and Economic Development in the Outer Islands of Indonesia, 1900-1941. Leiden: KITLV Press.

Wellan, J.W.J. 1932. Zuid-Sumatra: Economisch Overzicht van de Gewesten Djambi, Palembang, de Lampoengsche Districten En Bengkoelen. Wageningen: Veenman. 